\title{
Intracellular antigens released from Balb/c mice kidneys under chemically induced apoptosis and/or necrosis
}

\section{Antigeni intracellulari renali di topo Balb/c rilasciati in seguito ad apoptosi e/o necrosi chimicamente indotte}

\author{
R. Ramírez-Sandoval ${ }^{1,3}$, M. Vázquez-del-Mercado ${ }^{2}$, A. Daneri-Navarro ${ }^{1}$, E. López-Robles ${ }^{3}$, \\ J.J. Bollain-y-Goitia ${ }^{3}$, E. Avalos-Diaz ${ }^{3}$, R. Herrera-Esparza ${ }^{3}$ \\ ${ }^{1}$ Programa de Doctorado en Ciencias Biomédicas, Departamento de Fisiología, Centro Universitario de ciencias de la Salud, \\ Universidad de Guadalajara, México; \\ ${ }^{2}$ Instituto de Investigación en Reumatología y del Sistema Músculo Esquelético Centro Universitario de Ciencias de la Salud, \\ Universidad de Guadalajara, México; \\ ${ }^{3}$ Department of immunology, CBE, Universidad Autonoma de Zacatecas, Mexico
}

\begin{abstract}
RIASSUNTO
Questo studio valuta il possibile ruolo dell'apoptosi e della necrosi nell'esposizione di antigeni intracellulari da reni di topo Balb/c. L'apoptosi e la necrosi dei tessuti renali è stata indotta con esposizione a prodotti chimici. È stata quindi valutata l'espressione degli antigeni intracellulari $\mathrm{Sm}, \mathrm{RNP}$, Ro e La. I risultati confermano che gli antigeni intracellulari renali sono liberati ed esposti sulla superficie delle cellule apoptotiche e necrotiche e possono pertanto rappresentare un facile bersaglio per gli autoanticorpi. Ė ipotizzabile che questo meccanismo possa svolgere un ruolo importante nella patogenesi della nefrite lupica.
\end{abstract}

Reumatismo, 2008; 60(2):108-113

\section{INTRODUCTION}

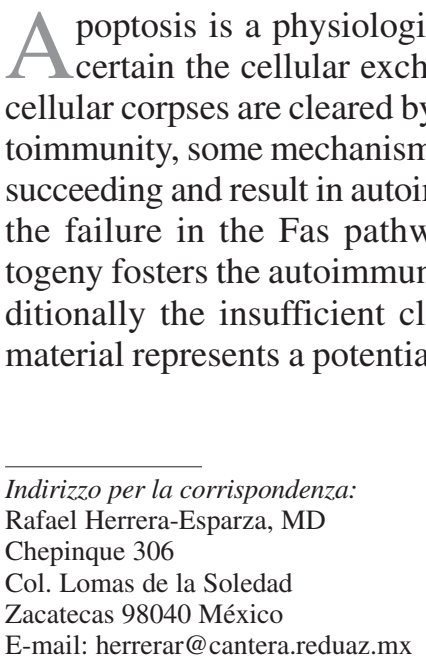

tivate the pre-existent auto-reactive clones, and may trigger the autoantibody production (1). Is now accepted that antigens from apoptotic origin are better targeted by autoantibodies (2-4), and the source of apoptotic remains is broad spread, nevertheless the skin is very important because is an easy target of the UV light, and may induce antibody deposition\resulting in skin lesions, this mechanism is important in SCLE (5). In other organs this mechanism can not explain the nature of the lesions, and mechanisms that induce the in situ formation of immune complexes is still under investigation; in the case of kidneys the major damage mediated by antibodies is ascribed to circulating immune complexes; however not always are detected, thus an alternative explanation is the in situ formation of these complexes. Different inflammatory mediators such as the TNF participate 
in lupus nephritis (6); this and other cytokines may trigger the Fas pathway, in consequence the kidney damage is associated to apoptotic or necrotic changes in glomerulus's. For this reason it is important to assess whether apoptosis or necrosis may increase the exposure of intracellular antigens, as a possible trigger mechanism capable to form in situ immune complexes, this issue was assessed in renal tissues from neonatal Balb/c mice.

\section{MATERIAL AND METHODS}

\section{Kidney biopsies}

Neonatal Balb/c mice were maintained on ice bath for ten minutes, then kidneys were obtained by dissection under stereoscopic microscope. Tissues were rinsed in Hank's solution and cultured in DMEM medium (Dubbleco's modified Eagle's Medium) supplemented with $10 \%$ fetal calf serum (Gibco, BRL Gaithersburg MD). Kidneys were grouped in number of five and cultured six hours in DMEM using polystyrene dishes at $37^{\circ} \mathrm{C}$ in $5 \%$ $\mathrm{CO} 2$. The experimental groups were the following: (A) Contol group, (B) Treated with $20 \mathrm{mM}$ camptothecin, (C) Treated with $20 \mathrm{mM}$ cycoheximide, (D) Treated with $20 \mathrm{ml}$ of $\mathrm{H}_{2} \mathrm{O}_{2}(0.2 \%)$, (E) Treated with $5 \mathrm{mM} \mathrm{mM} \mathrm{Cl} \mathrm{Hg}$. After incubation kidneys were fixed, embedded in paraffin and used for immunohistology and fluorescence. During this trial the guidelines for ethical conduct in the care and use of animals developed by APA was followed (http://www.apa.org/ science/anguide.html).

\section{Immunohistochemistry}

Slides containing $4 \mu \mathrm{m}$ sections of kidney were dewaxed, then permeabilized with $0.01 \%$ Triton X100/PBS and washed three times with PBS; endogenous peroxidase was blocked with $56^{\circ} \mathrm{C}$ heated horse serum inactivated. After washing, tissues were incubated 1 hour with anti-Ro (sc-19681 Santa Cruz, Biotechnology, Inc. Santa Cruz.CA) and anti-La, anti-Sm and anti-RNP obtained respectively from a patient with Sjögren disease (7), a patient who meet the ACR criteria for SLE classification (8), and a patient with mixed connective tissue disease (9). Monoclonal antibodies or human serum were diluted 1:1000 in 10\% BFS-PBS; after washings with PBS bound antibodies were tagged with rabbit anti-mouse IgG labeled with peroxidase in the case of the anti-Ro, meanwhile the human autoantibodies were tagged with goat anti-human IgG labeled with peroxidase. Color re- action was induced by 2, 2 diaminobenzydine$0.06 \% \mathrm{H}_{2} \mathrm{O}_{2}$ (Sigma, San Luois, MO) and stopped with $2 \mathrm{~N}$ sulphuric acid. Slides were finally evaluated by three observers. All assays were made in four replicas. The intensity of the color reaction obtained by immunohistochemistry was analyzed by KDS1 program (Kodak) measuring the sum of color intensity in pixels.

\section{TdT-mediated dUTP nick end labeling (TUNEL)}

TUNEL analysis was done according to the manufacturer's instructions (Roche Molecular Biochemicals. Penzberg, Germany). Nuclear stripping was performed on a cell monolayer by immersing the slides in $10 \mathrm{mM}$ Tris- $\mathrm{HCl}, \mathrm{pH} 8.0$ followed by $15 \mathrm{~min}$ in $20 \mathrm{mg} / \mathrm{ml}$ proteinase $\mathrm{K}$. Elongation of DNA fragments was done by incubation with reaction mixture (DDW, 10XTdT buffer (30mM Tris base, $140 \mathrm{mM}$ sodium cacodylate, $\mathrm{pH} 7.2,1 \mathrm{mM}$ cobalt chloride, 1mM DTT; $10 \%$ of the final volume), fluorescein-11-dUTP (0.5 mg dissolved in $1 \mathrm{ml}$ of $10 \mathrm{mM}$ Tris-HCl, $\mathrm{pH} 7.0$ ), and TdT enzyme ( 0.3 enzyme units $/ \mathrm{ml}$ ). Reaction was terminated by adding $300 \mathrm{mM} \mathrm{NaCl}, 30 \mathrm{mM}$ sodium citrate, and $\mathrm{pH}$ 8.0. To differentiate the true green tag of apoptotic cells from the background incorporation, cells were counterstained with $2 \%$ propidium iodide. By this procedure the non-apoptotic nuclei develop a red stain. The slides were washed, mounted, and examined using a confocal scanning microscope LSM (Axiovert 200M, Carl Zeiss, Göttingen, Germany). Combination of fluorescein filters with excitations of 450-490 $\mathrm{nm}$ and rodamin filters with emissions of 515-565 nm were used. Objectives were LCI "Plan-Neofluar" and image processing was done with a Zeiss LSM Image examiner. The rate of apoptotic cells by TUNEL was the percent of cells exhibiting green tag analyzing 100 fields. A positive control was included in all experiments as follows: kidney's sections incubated in DMEM without chemicals were digested with nucleases and then processed by TUNEL, theoretically under this condition most of the cells must be green tagged. The total cellular amount resulted in the addition of red and green tagged cells. Slides were evaluated by three different observers in a blind manner.

\section{Statistics}

Differences between samples were evaluated by non parametric statistics (ANOVA and unpaired $t$ test) using the PRISMA program. 


\section{RESULTS}

\section{Kidney cultures}

alb/c mice kidney's were successful cultured after twelve hours incubation and cell viability was determined by TUNEL, using this technique the percent of cell death was determined in 100 fields, all cells tagged in green were death, meanwhile those red tagged were considered living cells. The apoptotic percent in control group was irrelevant (less than $0.3 \%$ ).

\section{Apoptosis and necrosis analysis}

Chemicals produce cell death in approximately the forty percent of glomerular and tubular cells, there- fore differences between control and problem groups was significant different $\mathrm{p}<0.001$. Interestingly the cycloheximide was the most potent inducer of cell death, this was followed by camptothecin, surprisingly the mercury chloride was not the highest as was expected, this result may be explained by the poor solubility of this heavy metal; however the differences of cell death index among the groups of different chemicals was irrelevant (Table I).

\section{Cell death cause release of renal intracellular antigens}

As monitor the intracellular antigens release the following antibodies: anti-Sm, anti-RNP, anti-Ro

Table I - Chemically induced cell death measured by TUNEL.

\begin{tabular}{|ccccc|}
\hline Control & CPT & $\mathrm{CHX}$ & $\mathrm{Cl} 2 \mathrm{Hg}$ & $\mathrm{H}_{2} \mathrm{O}_{2}$ \\
\hline $0.3200 \pm 0.6337$ & $49.70 \pm 8.178$ & $52.10 \pm 11.94$ & $43.12 \pm 19.52$ & $40.75 \pm 15.00$ \\
vs & $\mathrm{P}<0.0001$ & $\mathrm{P}<0.0001$ & $\mathrm{P}<0.0001$ & $\mathrm{P}<0.0001$ \\
\hline Unpaired test & & & \\
\hline
\end{tabular}
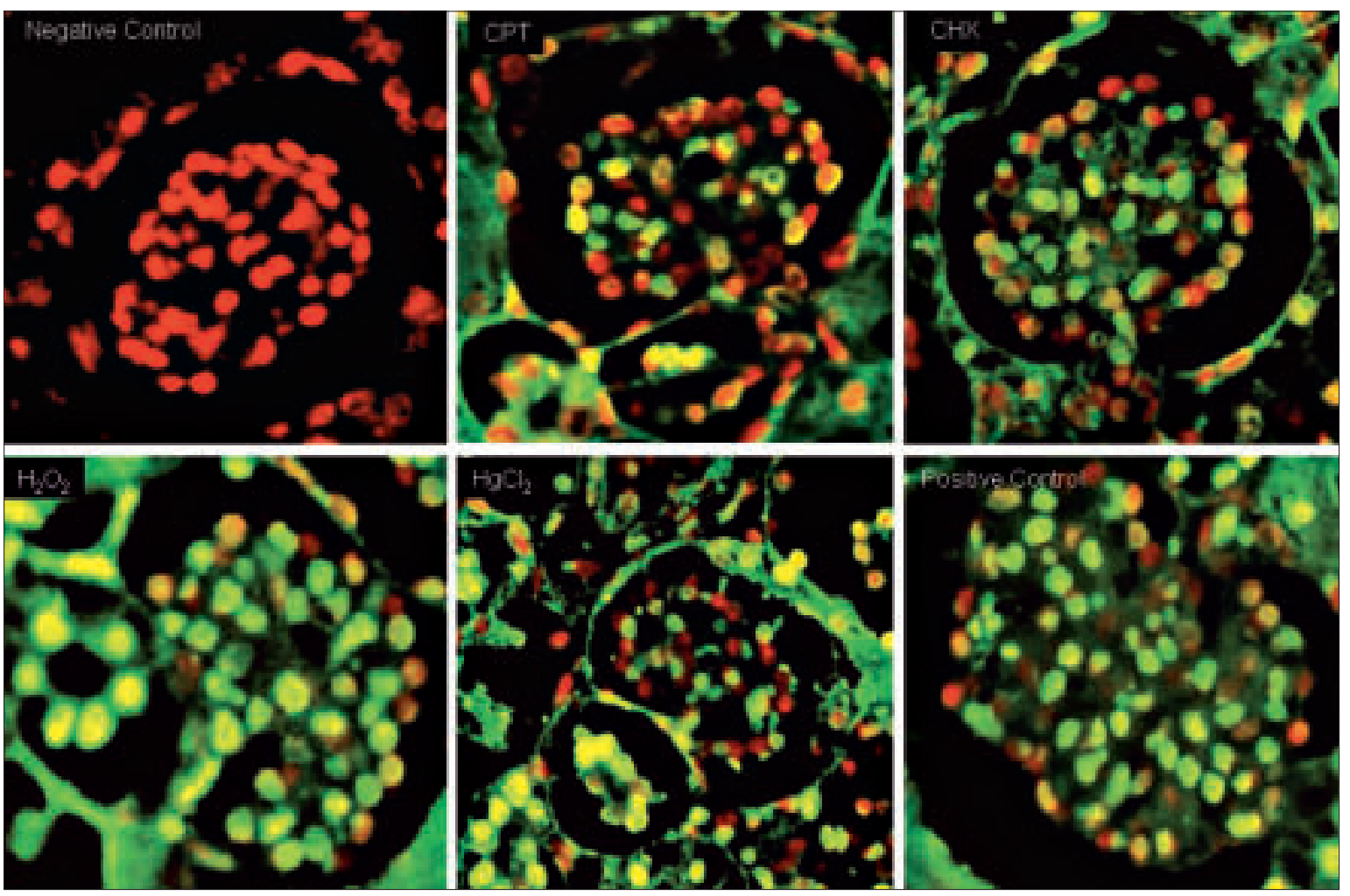

Figure 1 - TUNEL assay by fluorescence, the green tag indicate death cells, meanwhile the red tag correspond to the ethidium bromide incorporation by the living cells. Negative control corresponds to a kidney section incubated in DMEM medium without chemicals. Positive control correspond a kidney section incubated with DMEM in absence of chemicals, after sectioning the tissue was incubated with nucleases included in the commercial kit. 
Table II - Antigen expression by immunohistochemistry under chemically induced apopotosis and necrosis.

\begin{tabular}{|c|c|c|c|c|c|}
\hline Condition & A) Control & B) $\mathrm{La}$ & C) $R o$ & D) $\mathrm{Sm}$ & E) $R N P$ \\
\hline \multirow[t]{2}{*}{ 1) $\mathrm{CPT}$} & $82.85 \pm 17.46$ & $3725 \pm 1143$ & $2125 \pm 560.9$ & $4848 \pm 2527$ & $2285 \pm 538.90$ \\
\hline & vs $\rightarrow$ & $P<0.0001$ & $P<0.0001$ & $P<0.0001$ & $P<0.0001$ \\
\hline \multirow[t]{2}{*}{ 2) $\mathrm{CHX}$} & $92.60 \pm 22.79$ & $4705 \pm 1627$ & $4688 \pm 1646$ & $7138 \pm 2049$ & $6997 \pm 1997$ \\
\hline & vs $\rightarrow$ & $P<0.0001$ & $P<0.0001$ & $P<0.0001$ & $P<0.0001$ \\
\hline \multirow[t]{2}{*}{ 3) $\mathrm{Cl} 2 \mathrm{Hg}$} & $53.95 \pm 11.36$ & $4312 \pm 1633$ & $5252 \pm 1470$ & $4564 \pm 1945$ & $3375 \pm 1044$ \\
\hline & vs $\rightarrow$ & $P<0.0001$ & $P<0.0001$ & $P<0.0001$ & $P<0.0001$ \\
\hline \multirow[t]{2}{*}{ 4) $\mathrm{H} 2 \mathrm{O} 2$} & $81.50 \pm 21.34$ & $3032 \pm 1247$ & $3107 \pm 994.7$ & $6367 \pm 1712$ & $3560 \pm 1038$ \\
\hline & vs $\rightarrow$ & $P<0.0001$ & $P<0.0001$ & $P<0.0001$ & $P<0.0001$ \\
\hline \multirow[t]{2}{*}{ 5) DMEM } & $97.95 \pm 21.72$ & $716.1 \pm 301.7$ & $761.9 \pm 270.7$ & $800.4 \pm 247.7$ & $509.7 \pm 135.4$ \\
\hline & vs $\rightarrow$ & $P<0.0001$ & $P<0.0001$ & $P<0.0001$ & $P<0.0001$ \\
\hline \multirow[t]{4}{*}{$P$ value } & 5 Avs1 $A=0.0203$ & $5 \mathrm{Bvs} 1 \mathrm{~B}=0.0001$ & 5 Cvs1C $=0.0001$ & $5 \mathrm{Dvs} 1 \mathrm{D}=0.0001$ & 5 Evs $1 \mathrm{E}=0.0001$ \\
\hline & 5 Avs $2 A=0.0206$ & 5 Bvs $2 B=0.0001$ & 5 Cvs $2 C=0.0001$ & $5 \mathrm{Dvs} 2 \mathrm{D}=0.0001$ & 5 Evs $2 \mathrm{E}=0.0001$ \\
\hline & 5 Avs $3 \mathrm{~A}=0.1201$ & 5 Bvs $3 B=0.0001$ & 5 Cvs3C $=0.0001$ & $5 \mathrm{Dvs} 3 \mathrm{D}=0.0001$ & $5 \mathrm{Evs} 3 \mathrm{E}=0.0001$ \\
\hline & 5 Avs $4 \mathrm{~A}=0.8263$ & 5 Bvs $4 \mathrm{~B}=0.0001$ & 5 Cvs $4 \mathrm{C}=0.0001$ & $5 \mathrm{Dvs} 4 \mathrm{D}=0.0001$ & $5 \mathrm{Evs} 4 \mathrm{E}=0.0001$ \\
\hline
\end{tabular}

and anti-La were used for immunohistochemistry. The reactivity of autoantibodies against kidneys cultured in absence of chemicals was positive but low, such expression was significantly increased in apoptotic and necrotic tissues. Interestingly major antigen expression was caused by cyclohex- imide and camptothecin. The intensity of color reaction of the antigen-antibody interaction was expressed as the sum of intensities in pixels, by these method significant differences between controls and problems was observed $(\mathrm{p}<0.001)$. As expected the kidneys treated with chemicals express more
Figure 2 - Antigen expression by immunohistochemistry in kidneys submitted to apoptosis or necrosis by diverse chemicals $(\mathrm{CPT}=$ camptothecin. $\mathrm{CHX}=$ cycloheximide. $\mathrm{HgCl}_{2}=$ mercury chloride. $\mathrm{H}_{2} \mathrm{O}_{2}=$ hydrogen peroxide. DMEM = Dubblecco's modified Eagle's medium. Control slides were treated with normal human sera. DMEM correspond to kidneys incubated with culture media without chemicals.

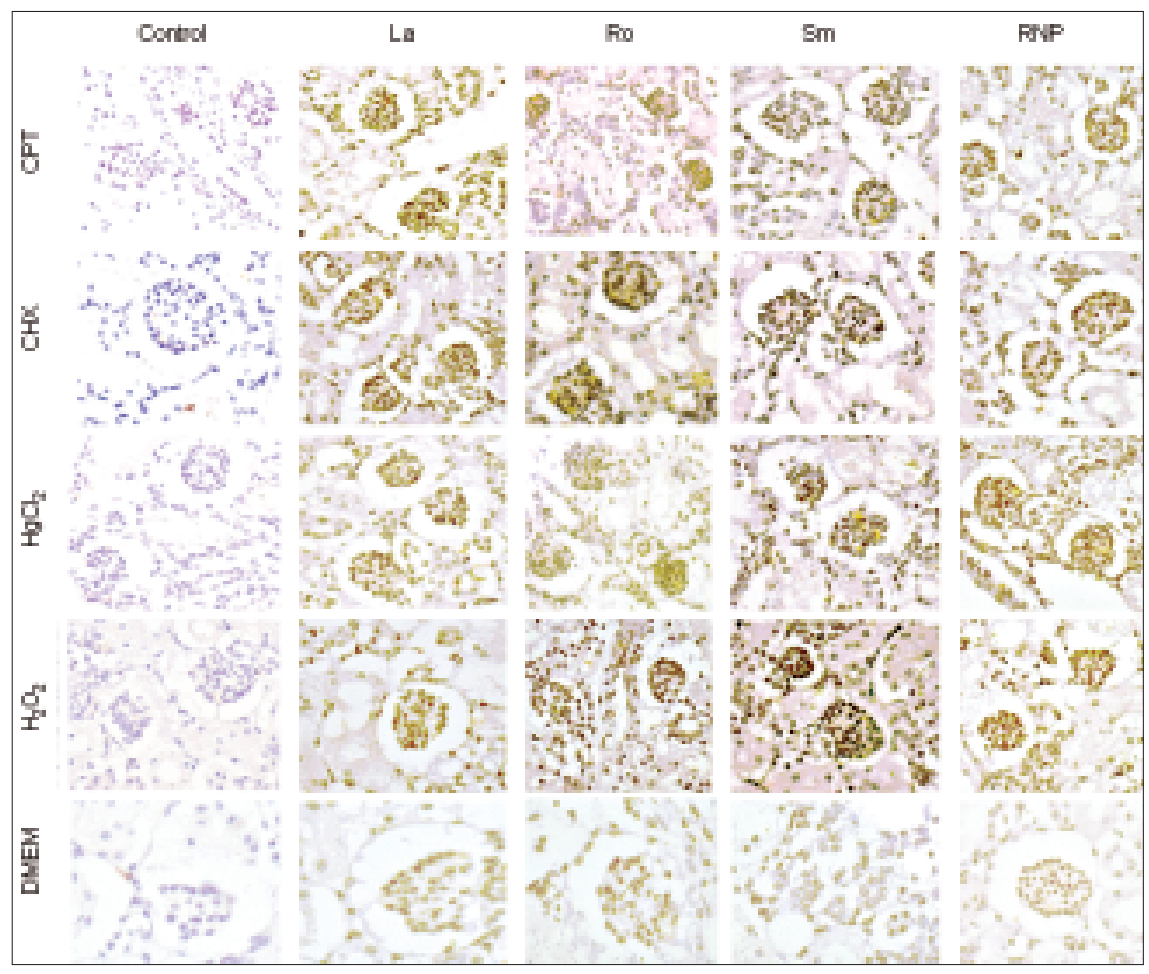


antigens than those without chemical inducers, therefore the difference among them was also significant $(p<0.001)$. Normal control sera resulted negative in all assays (Table II).

\section{DISCUSSION}

Present investigation questioned whether apoptosis increase the exposure of intracellular antigens as possible mechanism to explain formation of immune complexes in situ at renal level. Principal results of this work were:

1) Kidney cultures yielded reproducible results to assess the cell death induced by chemicals.

2) Cell death increased the expression of intracellular antigens such as La, Ro, Sm and RNP.

3) Reactivity of autoantibodies to intracellular antigens obtained from living renal cells was poor, nevertheless under apoptosis or necrosis enhance its reactivity.

In summary based in present results we can propose that apoptosis and necrosis of kidney constitute a possible antigenic source that may feed the glomerular damage in lupus nephritis.

Apoptosis normally occurs in developing vertebrate organs of mammals, and less than $3 \%$ of the nephrogenic region and the medullar papilla exhibit an apoptotic features. Normally the apoptot- ic remains are rapidly cleared by phagocytosis which is executed by the neighboring parenchyma $(10,11)$. After birth, apoptosis of renal cells is remarkable low and contributes to maintain the structure and function of the renal tissue. Apoptosis is critical in healing, but in lupus nephritis apoptosis may be increased by different mediators like the TNF (6) and TWEAK, the later is cytokine of the TNF superfamiliy, that activates the Fn14 receptor and regulates cell proliferation, cell death and inflammation $(12,13)$. In lupus nephritis the urinary of TWEAK levels are higher in patients with active disease (14); by this cytokine effect the glomerular apoptotic remains constitute a real source of antigens that may be easily targeted by cells or by autoantibodies (15). By this proposal we suggest that the release of apoptotic and necrotic remains in kidneys may trigger the autoantibody deposition in situ, and this may increase the renal damage of lupus nephritis; this mechanism has been substantiated in other diseases such as Sjogren's (16). Finally this local mechanism at renal level may be important in the lupus nephritis pathogenesis.

\section{Acknowledgements}

Part of this work was supported by CONACYT grant 194235 and PROMEP-UAZ-CA-5 Autoinmunidad.

\begin{abstract}
SUMMARY
The present investigation assesses the possible role of apoptosis and necrosis in intracellular antigen exposure of kidneys from Balb/c mice. Renal tissues were cultured and treated with chemicals to induce apoptosis and /or necrosis. The expression of intracellular antigens Sm, RNP, Ro and La were monitored with antibodies against these antigens. Main results confirm that renal intracellular antigens are released and exposed onto the surface of apoptotic and necrotic cells, therefore these antigens become an easy target of autoantibodies. This mechanism may be important in the lupus nephritis pathogenesis.
\end{abstract}

Parole chiave - Reni autoantigeni, autoanticorpi, apoptosis, necrosi.

Key words - Renal autoantigens, autoantibodies, apoptosis, necrosis.

\section{REFERENCES}

1. Herrera-Esparza R, Herrera-van-Oostdam D, LópezRobles E, Avalos-Díaz E. The role of apoptosis in autoantibody production. Reumatismo 2007; 59: 87-99.

2. Wu X, Molinaro C, Johnson N, Casiano CA. Secondary necrosis is a source of proteolytically modified forms of specific intracellular autoantigens: implications for systemic autoimmunity. Arthritis Rheum 2001; 44: 2642-52.
3. Ramírez-Sandoval R, Sánchez-Rodríguez SH, Herreravan Oostdam D, Avalos-Díaz E, Herrera-Esparza R. Antinuclear antibodies recognize cellular autoantigens driven by apoptosis. Joint Bone Spine 2003; 70: 18794.

4. Herrera-vanOostdam DA, Esparza-Ibarra E, RamírezSandoval R, Ortíz V, Bollain-y-Goitia JJ, Avalos-Diaz E, Herrera-Esparza R. Apoptosis and necrosis increase antigenicity of proteins recognized by antinuclear antibodies. Reumatismo 2004; 56: 156-61. 
5. Herrera-Esparza R, Villalobos R, Bollain-Y-Goytia JJ, Ramírez-Sandoval R, Sánchez-Rodriguez SH, PachecoTovar G, Avalos-Diaz E. Apoptosis and redistribution of the Ro autoantigen in Balb/c mouse like in subacute cutaneous lupus erythematosus. Clin Dev Immunol 2006; 13: 163-6.

6. Herrera-Esparza R, Barbosa-Cisneros O, VillalobosHurtado R, Avalos-Díaz E. Renal expression of IL-6 and TNF alpha genes in lupus nephritis. Lupus 1998; 7: $154-8$

7. Vitali C, Bombardieri S, Jonsson R, Moutsopoulos HM, Alexander EL, Carsons SE, et al. European Study Group on Classification Criteria for Sjögren's Syndrome. Classification criteria for Sjögren's syndrome: a revised version of the European criteria proposed by the American-European Consensus Group. Ann Rheum Dis 2002; 61: 554-8.

8. Tan EM, Cohen AS, Fries JF, Masi AT, McShane DJ, Rothfield NF, et al. The 1982 revised criteria for the classification of systemic lupus erythematosus. Arthritis Rheum 1982; 25: 1271-7.

9. Maddison PJ. Mixed connective tissue disease: overlap syndromes. Baillieres Best Pract Res Clin Rheumatol.2000; 14: 111-24.

10. Harriet S, Coles R, Burne JF, Raff MC. Large-scale normal cell death in the developing rat kidney and its reduction by epidermal growth factor. Development 1993; 118: 777-84.
11. Bollain-y-Goytia JJ, Meza-Lamas E, Lopez A, Avalos-Diaz E, Rodríguez-Padilla C, Herrera-Esparza R. Renal cell turnover results in a fine balance between apoptosis and cell proliferation. J Biol Res 2006; 6: 131-8.

12. Zhao Z, Burkly LC, Campbell S, Schwartz N, Molano A, Choudhury A, Eisenberg RA, Michaelson JS, Putterman C. TWEAK/Fn14 interactions are instrumental in the pathogenesis of nephritis in the chronic graft-versus-host model of systemic lupus erythematosus. J Immunol 2007; 179: 7949-58.

13. Sanz AB, Moreno JA, Sanchez-Nino MD, Ucero AC, Benito A, Santamaria B, Justo P, Izquierdo MC, Egido J, Blanco-Colio LM, Ortiz A. TWEAKing renal injury. Front Biosci 2008; 13: 580-9.

14. Schwartz N, Su L, Burkly LC, Mackay M, Aranow C, Kollaros M, Michaelson JS, Rovin B, Putterman C. Urinary TWEAK and the activity of lupus nephritis. J Autoimmun 2006; 27: 242-50.

15. Zykova SN, Seredkina NE, Rekvig OP. Glomerular Targets for Autoantibodies in lupus nephritis-An apoptotic origin. Ann NY Acad Sci 2007; 1108: 1-10.

16. van Woerkom JM, Geertzema JG, Nikkels PG, Kruize AA, Smeenk RJ, Vroom TM. Expression of Ro/SS-A and $\mathrm{La} / \mathrm{SS}-\mathrm{B}$ determined by immunohistochemistry in healthy, inflamed and autoimmune diseased human tissues: a generalized phenomenon. Clin Exp Rheumatol 2004; 22: 285-92. 